\title{
Identification and characterization of a salt stress- inducible zinc finger protein from Festuca arundinacea
}

\author{
Ruth C Martin ${ }^{1 *}$, Kira Glover-Cutter ${ }^{1}$, James C Baldwin² and James E Dombrowski ${ }^{1}$
}

\begin{abstract}
Background: Increased biotic and abiotic plant stresses due to climate change together with an expected global human population of over 9 billion by 2050 intensifies the demand for agricultural production on marginal lands. Soil salinity is one of the major abiotic stresses responsible for reduced crop productivity worldwide and the salinization of arable land has dramatically increased over the last few decades. Consequently, as land becomes less amenable for conventional agriculture, plants grown on marginal soils will be exposed to higher levels of soil salinity. Forage grasses are a critical component of feed used in livestock production worldwide, with many of these same species of grasses being utilized for lawns, erosion prevention, and recreation. Consequently, it is important to develop a better understanding of salt tolerance in forage and related grass species.
\end{abstract}

Findings: A gene encoding a ZnF protein was identified during the analysis of a salt-stress suppression subtractive hybridization (SSH) expression library from the forage grass species Festuca arundinacea. The expression pattern of FaZnF was compared to that of the well characterized gene for delta 1-pyrroline-5-carboxylate synthetase (P5CS), a key enzyme in proline biosynthesis, which was also identified in the salt-stress SSH library. The FaZnF and P5CS genes were both up-regulated in response to salt and drought stresses suggesting a role in dehydration stress. FaZnF was also up-regulated in response to heat and wounding, suggesting that it might have a more general function in multiple abiotic stress responses. Additionally, potential downstream targets of FaZnF (a MAPK [Mitogen-Activated Protein Kinase], GST [Glutathione-S-Transferase] and lipoxygenase L2) were found to be upregulated in calli overexpressing $\mathrm{FaZnF}$ when compared to control cell lines.

Conclusions: This work provides evidence that FaZnF is an AN1/A20 zinc finger protein that is involved in the regulation of at least two pathways initiated by the salt stress response, thus furthering our understanding of the mechanisms of cellular action during a stress that is applicable to commercial crops worldwide.

\section{Introduction}

With an expected population of over 9 billion by 2050 and added abiotic and biotic plant stresses due to climate change, there is an increased demand for agricultural production on marginal lands. Additionally, the salinization of arable land has dramatically increased over the last few decades [1,2]. Soil salinity is one of the major abiotic stresses responsible for reduced crop productivity worldwide [3]. As land becomes less amenable for conventional agriculture, plants grown on marginal

\footnotetext{
* Correspondence: Ruth.Martin@ars.usda.gov

'USDA-ARS National Forage Seed Production Research Center, 3450 S.W. Campus Way, Corvallis, OR 97331

Full list of author information is available at the end of the article
}

soils will be exposed to higher levels of soil salinity. Forage grasses are a critical component of feed used in livestock production worldwide, with many of these same species of grasses being utilized for lawns, erosion prevention, and recreation. Consequently, it is important to develop a better understanding of salt tolerance in forage and related grass species.

Since plants are sessile, they have developed mechanisms that enable them to sense stressful environmental conditions and to elicit complex interactions between signaling molecules and pathways to adapt to various stresses. In the genomic era, new methods for looking at plant abiotic stress responses have evolved. The availability of the genome sequence and other resources

\section{Biomed Central}


such as microarrays, knockout mutants, and ease of transformation of the model dicot, Arabidopsis, greatly advanced our understanding of how plants respond to stress, including knowledge on the various components utilized in the signaling and response pathways. More recently, the availability of sequencing in other model species as well as some crop species facilitated the use of microarrays to analyze genes that are up- or downregulated in response to specific stresses $[4,5]$. As sequencing became less cost prohibitive, high-resolution transcript profiling has been used to identify stress related genes and pathways in both monocot and dicot species [5]. In response to salt or dehydration stress, small molecules such as ABA and calcium are utilized by plants to induce various signalling cascades. These pathways use various proteins such as phospholipases, kinases, calmodulin, calcium-binding proteins and transcription factors to activate genes and pathways necessary for water-related stress tolerance (for reviews see: [2,6-11]) and are often targets for genetic modification to improve salt/drought tolerance in plants $[12,13]$.

One particular class of proteins which are involved in plant response to abiotic stresses are zinc finger proteins. Zinc finger proteins were first characterized by a motif present in a protein (TFIIIA) that contained zinc and had the ability to bind DNA [14]. Members of the zinc finger transcription factors are characterized by the number and arrangement of cysteine $(\mathrm{C})$ and histidine $(\mathrm{H})$ within the zinc finger $\left(\mathrm{C}_{2} \mathrm{H}_{2}, \mathrm{C}_{3} \mathrm{H}, \mathrm{C}_{2} \mathrm{C}_{2}, \mathrm{C}_{3} \mathrm{HC}_{4}, \mathrm{C}_{2} \mathrm{HC}_{5}\right)$ in combination with other hydrophobic amino acids essential for stabilizing the zinc finger $[14,15]$. The first plantspecific zinc finger, identified in petunia, belonged to the $\mathrm{C}_{2} \mathrm{H}_{2}$ type zinc finger family and contained a plant specific "QALGGH" domain [16]. In Arabidopsis, data mining revealed 171 genes coding for $\mathrm{C}_{2} \mathrm{H}_{2}$-type zinc finger proteins, of which 77 contained the plant specific "QALGGH" domain [17]. Similarly, $189 \mathrm{C}_{2} \mathrm{H}_{2}$ zinc finger proteins were data mined in rice, of which 26 were upregulated in response to abiotic stress (drought, and/or salt and/or cold), while 21 genes were down-regulated during abiotic stress [18]. Several Arabidopsis $\mathrm{C}_{2} \mathrm{H}_{2}$ zincfinger proteins function as transcription repressors during drought, cold and high salinity stress conditions [19]. Many $\mathrm{C}_{2} \mathrm{H}_{2}$-type zinc finger proteins have been shown to have a role in stress responses in plants [16,19-25], and many of the genes for these proteins, when overexpressed in Arabidopsis or tobacco, were shown to improve stress tolerance.

Another family of zinc finger proteins is characterized by the presence of A20 and AN1 zinc finger domains. The A20 domain was first identified in the A20 protein which was induced by a tumor-necrosis-factor in human endothelial cells [26]. The AN1 domain was initially identified as a putative zinc finger domain in an ubiquitin-like protein (AN1) from Xenopus laevis [27]. The first plant A20/AN1 zinc finger protein (OSISAP1) identified and characterized from rice, was shown to be induced by multiple stresses including cold, desiccation, salt, submergence, heavy metals, and injury, as well as ABA (Abscisic Acid). When this gene was overexpressed in tobacco, it conferred tolerance to multiple stresses (cold, dehydration and salt) during germination and early seedling growth stages [28]. Subsequently Rice Stress Associated Proteins (OsSAP 1-18) containing A20 and/or AN1 zinc fingers were identified by in silico analysis and compared to Arabidopsis A20/AN1 SAPs (AtSAP 1-10) [29]. There are 11 Rice SAPs (OsSAP1-11) that contain single A20 and AN1 zinc finger domains at the $\mathrm{N}$ and $\mathrm{C}$ termini, respectively. OsSAP12 contains two A20 zinc finger domains at the $\mathrm{N}$-terminus and an AN1 zinc finger at the $\mathrm{C}$ terminus. There are several OsSAP proteins that only contain one (OsSAP13-15) or two (OsSAP16-17) AN1 zinc finger domains, while OsSAP18 only contains the A20 zinc finger domain. Arabidopsis has 10 SAPs (AtSAP1-10) which contain both the A20 and AN1 zinc finger domains, 3 SAPs (AtSAP11-13) with two AN1 zinc-finger domains and one SAP (AtSAP14) with a single AN1 zinc finger [29].

Expression analysis under different abiotic stressful conditions revealed that many of these genes were induced in response to salt and dehydration stress. Overexpression of several of these genes or homologs from other species has been shown to increase tolerance to one or more of various abiotic stresses (salt, drought, cold, and/or heat) [28,30-33], but in one case overexpression increased tolerance to cold, but increased sensitivity to salt and drought [34]. Overexpression of AtSAP10 confers tolerance to heavy metals (nickel, manganese, zinc) and high temperature stress [35]. This zinc finger family of proteins shows potential for increasing or stabilizing crop production on marginal soils and during increasing abiotic stress conditions due to climate change.

In this paper, we describe the characterization of a gene encoding an A20/AN1 zinc-finger protein that was identified during the analysis of a salt-stress suppression subtractive hybridization ( $\mathrm{SSH}$ ) expression library in F. arundinacea, a moderately salt tolerant glycophyte http://www.salinitymanagement.org/Salinity\%20Management\%20Guide/cp/cp_7_table-1.html[36]. The expression pattern of $\mathrm{FaZnF}$ was compared to the well characterized dehydration stress tolerance gene, delta 1-pyrroline-5-carboxylate synthetase (P5CS). Expression levels of both genes were analyzed in response to different levels of salinity and to seven other forms of abiotic stress. F. arundinacea calli, which were transformed to over-express $F a Z n F$, were used to identify potential downstream targets of FaZnF. In this report we present 
evidence that $\mathrm{FaZnF}$ plays a role in dehydration stress responses and is also responsive to heat and wounding stress in tall fescue.

\section{Materials and methods \\ Plant materials}

F. arundinacea (tall fescue) seeds were planted in 4-inch square pots (volume approximately $750 \mathrm{~mL}$ ) in SB40 Sunshine Growing Mix (Sun Gro Horticulture, Canada). Plants were fertilized weekly using Technigro 20-18-20 all-purpose fertilizer (Sun Gro Horticulture, Canada). Plants were grown in a Conviron E15 (Conviron, Winnipeg, Canada) growth chamber under an 8-hr photoperiod at $21^{\circ} \mathrm{C}$ day and $18^{\circ} \mathrm{C}$ night. Plants were grown for 6 weeks and pots containing 12-16 plants were then used for various stress treatments described below. At the designated times, the aerial portions of 6-7 plants were collected, immediately frozen in liquid nitrogen and stored at $-80^{\circ} \mathrm{C}$ for future analysis.

\section{Stress treatments}

\section{Salt Stress}

Plants were subjected to salt stress by treating the soil with $500 \mathrm{~mL}$ of $500 \mathrm{mM} \mathrm{NaCl}$. Plants showed signs of mild wilting in the leaf blades after $1 \mathrm{hr}$. The aerial portions of 6-7 plants were collected 12 and $24 \mathrm{hr}$ after salt treatment, immediately frozen in liquid nitrogen and stored at $-80^{\circ} \mathrm{C}$.

\section{Salt concentration analysis}

Plants were grown in soil for 6 weeks. Each pot containing 10-14 plants was treated with $500 \mathrm{~mL}$ of one of the following: $0 \mathrm{mM}, 100 \mathrm{mM}, 200 \mathrm{mM} 300 \mathrm{mM}, 400 \mathrm{mM}$ or $500 \mathrm{mM} \mathrm{NaCl}$ salt solution. Plants treated with 0-300 mM $\mathrm{NaCl}$ did not show any visible signs of wilting over the $24 \mathrm{hr}$ period, but plants treated with 400 and $500 \mathrm{mM}$ $\mathrm{NaCl}$ showed signs of mild wilting but recovered within the 24-hr treatment period. The aerial portions of 6-7 plants were collected at 0,12 and $24 \mathrm{hr}$, immediately frozen in liquid nitrogen and stored at $-80^{\circ} \mathrm{C}$.

\section{Osmotic stress}

Plants were subjected to osmotic stress by treating the soil with $500 \mathrm{~mL}$ of $12.87 \%$ polyethylene glycol 6000 solution (PEG). Plants showed mild wilting of leaf blades after $1 \mathrm{hr}$ of treatment. The aerial portions of 6-7 plants were collected after 12 and $24 \mathrm{hr}$ of stress treatment.

\section{Wilt (Drought)}

To induce drought stress, watering was stopped and pots were allowed to dry overnight. After $24 \mathrm{hr}$ some very mild wilting was observed. Tissue was collected at 24 and $48 \mathrm{hr}$ after watering was stopped.

\section{UV Stress}

Plants were laid on their side and irradiated for $5 \mathrm{~min}$. Two hand-held 254-nm UV short-wave devices (Model UVG-11, Ultra-violet Products Inc, USA) were held
12-15 $\mathrm{cm}$ above the stems and leaves. Tissue limpness was observed after irradiation and samples from 6-8 plants were collected 1 and $8 \mathrm{hr}$ post treatment.

\section{Heat stress}

Plants were subjected to $40^{\circ} \mathrm{C}$ in a Conviron E15 Growth Chamber to simulate heat stress. The plants were well watered and placed in a shallow pan of water to maintain adequate hydration during heat stress treatments. Tissue from 6-8 plants was collected after 2 and $8 \mathrm{hr}$ of heat stress.

\section{Wounding}

Plants were mechanically wounded by closing a hemostat perpendicularly across the leaves and stems 3-5 times. Aerial plant tissue was collected $12 \mathrm{hr}$ after wounding.

\section{Cold stress}

Plants were subjected to $4^{\circ} \mathrm{C}$ for $24 \mathrm{hr}$. Tissue was collected from plants after $24 \mathrm{hr}$ in the cold.

\section{Control tissue}

Control tissue was collected from plants that were untreated and watered normally. All tissues were collected, immediately frozen in liquid nitrogen and stored at $-80^{\circ} \mathrm{C}$.

\section{Cloning of FaZnF gene and construction of Agrobacterium vector, pVec8.Ubi-ZnF}

The 5' end of $F a Z n F$ was isolated previously with a partial clone from a tall fescue salt-stress Subtractive Suppression Hybridization ( $\mathrm{SSH}$ ) library. This library was constructed and analyzed as described in an earlier paper except tall fescue tissue was used instead of L. temulentum [37]. In the analysis of the tall fescue SSH library, we confirmed salt induced expression of selected genes by Northern analysis (Dombrowski and Baldwin, unpublished results). Genes were selected based on homology to genes described in other systems that were shown to be involved in salt stress. Northern analysis confirmed that $F a Z n F$ was up-regulated by salt stress.

RACE (rapid amplification of cDNA ends) was used to isolate the 3' end of the gene. Total RNA was isolated from leaf/crown tissues of $F$. arundinacea plants which had been subjected to a 20-hr salt stress treatment, using TRIzol reagent (Life Technologies, Gaithersburg, MD) following the manufacturer's instructions. RNA was reverse transcribed to cDNA using SuperScript III Reverse Transcriptase (Invitrogen, Carlsbad, CA) according to the manufacturer's protocol with the modified oligo(dT) primer (5'-GGCCACGCGTCGACTAGTACT ${ }_{17}-3^{\prime}$ ). The resulting cDNA was used for PCR amplification in a $25 \mu \mathrm{l}$ reaction containing $1 \times$ HotStar Taq Master Mix (Qiagen, Chatsworth, CA), $1 \mu \mathrm{l} \mathrm{cDNA}$, and $0.4 \mu \mathrm{M}$ of each primer (5'GCCCCCAAAGGCCCAAGCAGGTG-3' and 5'-GGCCA CGCGTCGACTAGTAC-3'). The PCR cycle was as 
follows: an initial denaturation at $94^{\circ} \mathrm{C}$ for $14 \mathrm{~min} ; 7$ cycles of $94^{\circ} \mathrm{C}$ for $1 \mathrm{~min}, 72^{\circ} \mathrm{C}$ for $2.25 \mathrm{~min}$; 35 cycles of $94^{\circ} \mathrm{C}$ for $1 \mathrm{~min}, 67^{\circ} \mathrm{C}$ for $45 \mathrm{sec}, 72^{\circ} \mathrm{C}$ for $1 \mathrm{~min}$; with a final extension at $72^{\circ} \mathrm{C}$ for $10 \mathrm{~min}$. The initial PCR was followed with a nested PCR reaction using primers (5'-CAACTGCC GGTGCGGGAACCTGTACCTC and 5'-GGCCACGCG TCGACTAGTAC-3') and the same cycling conditions as used for the primary PCR. A 510-base pair product was gel purified, ligated into the p-GEM-T Easy vector (Promega, Madison, WI), cloned and sequenced. A BLAST search confirmed high homology to the $\mathrm{ZnF}$ genes from other species.

Primers were designed using the 5' sequence information from the initial salt-stress clone and the sequence from 3' RACE to obtain the complete $F a Z n F$ gene. An initial PCR was performed using primers (5'-GGGC AGGTCAGAATTGCTCG-3' and 5'-CGATTACTAGTTACTATTACCGGTTGCG-3') at a concentration of $0.6 \mu \mathrm{M}$ each with $1 \times$ HotStarTaq Master Mix (Qiagen) and $1 \mu \mathrm{l}$ of cDNA. Reaction conditions were as follows: an initial denaturation at $94^{\circ} \mathrm{C}$ for $14 \mathrm{~min}$ followed by 35 cycles of $94^{\circ} \mathrm{C}$ for $1 \mathrm{~min}, 52^{\circ} \mathrm{C}$ for $1.5 \mathrm{~min}, 72^{\circ} \mathrm{C}$ for $1.5 \mathrm{~min}$; with a final extension at $72^{\circ} \mathrm{C}$ for $10 \mathrm{~min}$. This PCR reaction was followed by nested PCR using the primers (5'-ATGGATCCCGCCGGAGAG-3'; BamH I site underlined) and (5'-ATGGTACCACAGATTACAGA GTGC-3'; Kpn I site underlined) at a concentration of $0.6 \mu \mathrm{M}$ each with $1 \times$ HotStarTaq Master Mix (Qiagen) and $0.3 \mu \mathrm{l}$ of the primary PCR product. Cycling parameters were as in the primary reaction with the exception that the annealing temperature was $59^{\circ} \mathrm{C}$. An 848 -bp product was gel purified, ligated into the p-GEM-T Easy vector (Promega), cloned and sequenced. A BLAST search confirmed high homology to other $Z n F$ genes. The purified $\mathrm{FaZnF}$ clone was digested with Kpn I and BamH I and ligated into the $B a m \mathrm{H}$ I/Kpn I digested pVec8.Ubi vector using T4 DNA ligase in $1 \times$ T4 ligase buffer (New England Biolabs, Ipswich, MA). The pVec8.Ubi vector was obtained from CSIRO (Commonwealth Scientific and Industrial Research Organisation; Australia) [38,39]. The final clone was sequenced to verify complete insertion into the vector.

RACE was also used to isolate the 5' and 3' regions of the P5CS partial clones identified by PCR-based SSH library analysis [37]. Total RNA from leaf/crown tissues of L. temulentum plants subjected to a 12-hr salt stress treatment was isolated using TRIzol reagent (Life Technologies, Gaithersburg, MD) following manufacturer's instructions. RNA was prepared for 5'RACE, and firststrand cDNA synthesis was performed with the GeneRacer $^{\mathrm{TM}}$ Oligo dT Primer included with the SuperScript ${ }^{\mathrm{TM}}$ III RT module following the manufacturer's instructions (Invitrogen, Carlsbad, CA). For 5' RACE, the cDNA was amplified with a gene-specific primer (5'-TGCCTCTCGG AATAACAAGGTCAATCA-3') and the kit 5' primer. For 3' RACE, the cDNA was amplified with the kit 3' RACE primer and a gene specific primer (5'-TCGGCTGACATGGATATGGCAAAACG-3'). The PCR reaction conditions were as follows: 5 cycles of $98^{\circ} \mathrm{C}$ for $10 \mathrm{sec}, 70^{\circ} \mathrm{C}$ for $5 \mathrm{sec}$ (decreasing $2^{\circ} \mathrm{C} / \mathrm{cycle}$ ), $72^{\circ} \mathrm{C}$ for $1 \mathrm{~min} 30 \mathrm{sec}$; followed by 25 cycles of $98^{\circ} \mathrm{C}$ for $10 \mathrm{sec}, 60^{\circ} \mathrm{C}$ for $5 \mathrm{sec}, 72^{\circ} \mathrm{C}$ for $1 \mathrm{~min}$ $30 \mathrm{sec}$; followed by a final extension at $72^{\circ} \mathrm{C}$ for $10 \mathrm{~min}$. PCR products were purified and sequenced. Based on these sequences, primers were designed to amplify the coding sequence with an extension homologous to the vector (underlined) at each end (5'-CGACTCTAGAGGATCCATGGGCAGGGGAGGCATCGGA-3' and 5'-CG GTACCCGGGGATCCGAATCCTCTACCTGCAATCAATG-3') to facilitate In-fusion PCR Cloning (Clonetech, $\mathrm{Ca}$ ) for future experiments.

\section{Phylogenetic analysis of $\mathrm{FaZnF}$}

The FaZnF cDNA and protein sequences were subjected to BLAST searches at NCBI (National Center for Biotechnology Information; http://blast.ncbi.nlm.nih.gov/) against the $\mathrm{nr}$ (nonredundant) nucleotide and protein databases to provide annotation information and ortholog sequences from other species $[40,41]$. Closely related DNA and protein sequences, the top alignment from each genera, were used for phylogenetic analysis and tree construction at the "Phylogeny.fr" website [42]. Additionally, the Stress Associated Protein (SAP) sequences from rice and Arabidopsis and the most closely related Brachypodium sequences containing at least one of each of the A20/AN1 domains were used for a phylogenetic analysis.

\section{Probe construction}

Primer3 software [43] was used to design primers for P5CS probe synthesis (5'-CATCAAGACCCTCTGTC 'TTG-3' and 5'-GTATATTCTGGGATAATGACAG-3') based on the LtP5CS sequence. RNA from salt stressed tall fescue tissue was used to produce cDNA, as described above, which was used for PCR to produce an $\sim 1.2 \mathrm{~kb}$ DIG-labeled P5CS probe using the PCR DIG Probe Synthesis Kit (Roche-Applied Science, IN) following the manufacturer's instructions. The PCR reaction conditions were as follows: an initial denaturation at $94^{\circ} \mathrm{C}$ for $4 \mathrm{~min}$; followed by 30 cycles of $94^{\circ} \mathrm{C}$ for $30 \mathrm{sec}, 55^{\circ} \mathrm{C}$ for $30 \mathrm{sec}$, $72^{\circ} \mathrm{C}$ for $1.0 \mathrm{~min}$; with a final extension at $72^{\circ} \mathrm{C}$ for $10 \mathrm{~min}$. Probe was used at $2 \mu \mathrm{l} / \mathrm{mL}$ of hybridization solution (Note: FaP5CS and LtP5CS sequences have 96\% homology in $1.1 \mathrm{~kb}$ of this region; data not shown).

Primer3 software [43] was used to design primers for $Z n F$ probe synthesis (5'-CGAGGGCTTTCTCGTATCAGTA-3' and 5'-GAGTGCTAGCTAAATGCGAAGC$\left.3^{\prime}\right)$ to produce an $\sim 800$ bp DIG-labeled $Z n F$ probe 
using DIG labeled dUTP (Roche-Applied Science, IN) for PCR following the manufacturer's recommendations. ExTaq Polymerase (Takara, WI) was used with the following PCR reaction conditions: an initial denaturation at $95^{\circ} \mathrm{C}$ for $4 \mathrm{~min}$; followed by 35 cycles of $94^{\circ} \mathrm{C}$ for $30 \mathrm{sec}, 60^{\circ} \mathrm{C}$ for $30 \mathrm{sec}, 72^{\circ} \mathrm{C}$ for $1.0 \mathrm{~min}$; with a final extension at $72^{\circ} \mathrm{C}$ for $10 \mathrm{~min}$. Probe was used at $2 \mu \mathrm{l} / \mathrm{mL}$ of hybridization solution.

\section{RNA gel blot analysis of genes}

Genes coding for P5CS and FaZnf were subjected to further analysis by RNA blot analysis. Harvested tissue from $F$. arundinacea plants that had been subjected to various stresses, was ground to a powder in liquid nitrogen using a precooled mortar and pestle. Total RNA extractions from these ground tissues were performed using TRIzol reagent (Life Technologies, Gaithersburg, $\mathrm{MD})$ following the manufacturer's instructions. Ten $\mu \mathrm{g}$ of total RNA isolated from selected/treated $F$. arundinacea plant tissue was electrophoretically separated on $1.2 \%$ denaturing formaldehyde agarose gels and blotted onto Hybond N+ nylon membranes [44]. Regions of selected genes were amplified by PCR using gene-specific primers and DIG labeled dUTP. The membranes were hybridized overnight with a DIG-labeled probe in a solution containing 15\% SDS, $0.25 \mathrm{M} \mathrm{NaPO}_{4}$ pH 7.2, 1 mM EDTA, 0.5\% blocking solution (Blocking solution: 10\% Boehringer-Mannheim blocking reagent, $100 \mathrm{mM}$ maleic acid $\mathrm{pH}$ 8.0, and $1 \mathrm{M} \mathrm{NaCl}$ ). Filters were washed in a solution

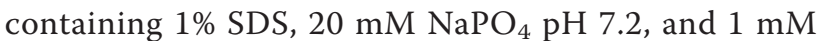
EDTA at $60^{\circ} \mathrm{C}$ for three 30-min washes. The blots were then blocked and incubated with anti-digoxigenin-alkaline phosphatase antibodies and washed following the manufacturer's instructions (Roche; IN). The chemiluminescent substrate, CDP-Star (Roche; IN), was applied to the blots and light emission was detected on X-ray film.

\section{Transformation of suspension cells with $\mathrm{FaZnF}$ Generation of tall fescue suspension cultured cell lines}

Tall fescue (TF) suspension cultured cells were derived from calli induced when juvenile plants or seeds were cultured on Callus Induction Media D (CIM D: MS salts with $5 \mathrm{mg} / \mathrm{L}$ 2,4-D, $30 \mathrm{~g}$ sucrose, $8 \mathrm{~g}$ Phytagar and $110 \mathrm{mg} / \mathrm{L}$ Nitsch \& Nitsch Vitamins). After 4 weeks of incubation, callus tissues generated from diced seed or explant material were visually selected and propagated by sub-culturing on the same medium every two weeks. After 2-3 months, the friable callus tissue that developed was transferred to $30 \mathrm{~mL}$ of liquid suspension induction medium (SIM: $4.3 \mathrm{~g}$ MS salts, $10 \mathrm{mg}$ 2,4-D and $30 \mathrm{~g}$ sucrose) [45] in a 125-mL Erlenmeyer flask and placed on a rotary shaker (195 rpm) in the dark at RT. After 1-2 months, the established suspension cultured cell lines were transferred into maintenance medium (MM: MS basal medium containing/L;
$5 \mathrm{mg}$ 2,4-D, $30 \mathrm{~g}$ sucrose, $1 \mathrm{mg}$ thiamine, $100 \mathrm{mg}$ myoinositol and $1 \mathrm{mM}$ EDTA). All cell lines used in this study are over seven years old. TF suspension cell lines were maintained in $40 \mathrm{~mL}$ of medium in 125 -mL Erlenmeyer flasks on orbital shakers $(195 \mathrm{rpm})$ in the dark. Cells $(10 \mathrm{~mL})$ were sub-cultured every 7 days into $30 \mathrm{~mL}$ of fresh sterile medium.

\section{Preparation of Agrobacterium}

The Agrobacterium vector pVec8.Ubi-FaZnF was introduced into Agrobacterium AGL-1 using the freeze thaw method [46]. Agrobacterium AGL-1 containing pVec8. Ubi-FaZnF was cultured on YEP agar plates containing $30 \mu \mathrm{g} / \mathrm{mL}$ rifampicin, $80 \mu \mathrm{g} / \mathrm{mL}$ carbenicillin and $100 \mu \mathrm{g} /$ $\mathrm{mL}$ spectinomycin and incubated at $28^{\circ} \mathrm{C}$ to obtain individual colonies. An individual colony was used for transformation studies following Gelvin's protocol [47] with a slight modification. Briefly AGL-1 containing pVec8.UbiFaZnF was grown overnight in YEP medium containing rifampicin at $30 \mu \mathrm{g} / \mathrm{mL}$, carbenicillin at $80 \mu \mathrm{g} / \mathrm{mL}$, and spectinomycin at $100 \mu \mathrm{g} / \mathrm{mL}$. The next day, $0.5-1 \mathrm{~mL}$ of the Agrobacterium overnight culture was added to $50 \mathrm{~mL}$ of $A B$ sucrose minimal medium containing rifampicin, carbenicillin and spectinomycin at the same concentration. After growing overnight at $28^{\circ} \mathrm{C}$, the bacteria were centrifuged and resuspended in $50 \mathrm{~mL}$ induction medium containing $100 \mu \mathrm{M}$ acetosyringone. The bacterial cultures were placed in two $50-\mathrm{mL}$ conical Falcon tubes on a rocker shaker overnight at room temperature. Transformation was performed using Agrobacterium in the induction medium.

\section{Agrobacterium mediated transformation of suspension cell} cultures

Suspension cell cultures eight days after subculturing were used for transformation experiments. Cells were allowed to settle and then approximately $4 \mathrm{~mL}$ of cells was transferred from the flask to a sterile disposable $100 \times 20 \mathrm{~mm}$ Petri dish (Fisher Cat. No. 0875711Z) for transformation. Excess media was removed from the plates, and $1 \mathrm{~mL}$ of Agrobacterium was added to the cells and allowed to sit for approximately $2 \mathrm{hr}$. Transformation efficiency was improved when $10 \mu \mathrm{l}$ of $1 \mathrm{M}$ $\mathrm{NaOH}$ and $50 \mu \mathrm{L}$ of cysteine (Sigma C7880; St. Louis, MO.; Stock $20 \mathrm{mg} / \mathrm{mL}$; final concentration $0.5 \mathrm{mg} / \mathrm{mL}$ ) were added as two droplets to a clear area of each original plate. An additional $1 \mathrm{~mL}$ of Agrobacterium culture was first mixed with the $\mathrm{NaOH}$ and cysteine solutions and then mixed with the suspension cells. The plates were then wrapped with Nescofilm (Karlan Reseach Products; Cottonwood, AZ) and placed in the dark at RT for three days. Following co-cultivation, $3 \mathrm{~mL}$ of $\mathrm{MM}$ medium was added to the plate and pipetted over the cells to loosen the cells and bacteria that were adhering to the plate. The medium was removed from the plate and the cells were washed with $2 \mathrm{~mL}$ of $\mathrm{MM}$ medium 
containing $400 \mathrm{mg} / \mathrm{L}$ timentin (GlaxoSmithKline; Research Triangle Park, NC) and $40 \mathrm{mg} / \mathrm{L}$ L-cysteine. This medium was removed and replaced with $10 \mathrm{~mL}$ of the same medium. Cultures were grown at room temperature in the dark on an Innova platform shaker at $80 \mathrm{rpm}$. Three days later, hygromycin (Cat. \#10687-010; Invitrogen; Carlsbad, CA) was added to a final concentration of $40 \mathrm{mg} / \mathrm{L}$ to select for transformants. The culture medium was removed each week and replaced with fresh media. After approximately 4-6 weeks, the transformed cells grew into larger clusters which were removed and placed on solid MM2 media containing $400 \mathrm{mg} / \mathrm{L}$ timentin, $40 \mathrm{mg} / \mathrm{L}$ hygromycin, $40 \mathrm{mg} / \mathrm{L}$ cysteine and $3 \mathrm{~g} / \mathrm{L}$ gelrite (Research Products International; Mt. Prospect, IL). After approximately 2-4 weeks, clusters that grew were spread thinly on new plates and were allowed to grow for 2 weeks to maximize the possibility that the selected clusters were derived from a single transformation event. A single homogenous culture representing each original cluster was selected and grown up as an individual line. Five independent lines overexpressing FaZnF and two non-transformed control lines were used for the Reverse Transcription quantitative PCR experiments (RT qPCR).

\section{RNA extraction and cDNA synthesis}

Two non-transformed control calli (obtained from the same original suspension cell culture used for transformation) and five FaZnF overexpressing calli were harvested for RNA extraction. Briefly, $0.5 \mathrm{~g}$ of calli was submerged in Trizol and homogenized for 30 seconds (Ultra-Turrax ${ }^{\circledR}$ T25 at a setting of 4 ). Samples were then frozen at $-80^{\circ} \mathrm{C}$, quickly thawed at $37^{\circ} \mathrm{C}$, and centrifuged for $5 \mathrm{~min}$ at $\sim 12500 \times \mathrm{g}$ to remove cellular debris. Continuation of RNA extraction followed the manufacturer's protocol for Trizol (Invitrogen, Carlsbad, Ca). After RNA purification, samples were treated with Turbo DNase following the manufacturer's instructions (Ambion, Austin, TX), and cDNA was synthesized using $5 \mu \mathrm{g}$ of RNA from each sample with the SUPERSCRIPT III RT kit (Invitrogen, Carlsbad, CA) primed with random hexamers.

\section{RT qPCR analysis}

Based on contig sequences for each potential stressassociated target gene (MYC, lipoxygenase L2, Gst24, and eIF1) and sequences of reference genes GAPDH and UBC for $F$. arundinacea from the TIGR database, specific qPCR primers were designed (Table 1). Two reference genes were used in this study to reduce the possibility that the selected genes might themselves be changing with overexpression of $F A Z n F$ and to increase confidence in the fold changes of other genes relative to reference genes. Sequences of all contigs/genes used in this paper are reported in Supplementary Figure 1. Roche LightCycler Probe Design Software 2.0 was used to design primers with an average melting temperature of $62^{\circ} \mathrm{C}$ that, when used for PCR, would produce a product between 75 and 125 bp. Quantitative PCR was performed in $20 \mu \mathrm{l}$ reactions in 96-well plates with BioRad iQSyber Supermix using a BioRad iQ5 Real-time PCR detection system (Bio-Rad Laboratories, Hercules, CA). Serial dilution standard curves from pooled cDNA samples were utilized to test the efficiency and specificity of each primer (Table 1). The efficiency calculation is based on the slope of the serially diluted points: $\mathrm{E}=$ $-1+10^{(-1 / \text { slope })}$, and the specificity of each primer was analyzed by its single point dissociation curve. The close range of efficiencies between the targets and controls allowed for a $\triangle \triangle C T$ analysis using GAPDH or UBC as calibrators [48]. Calculation of relative mRNA followed the equation: $2^{(-\Delta \text { CtSample }-\Delta \text { CtCalibrator })}$ as described by Livak and Schmittgen [49]. For each $20 \mu$ l reaction, $0.5 \mu \mathrm{l}$ of sample cDNA was used. Analysis was performed from five independently transformed biological replicates of overexpressing calli and repeated on three independent qPCR plates. Reactions were performed with the following PCR cycle: Initial denaturation for $3 \mathrm{~min}$ at $95^{\circ} \mathrm{C} ; 50$ cycles of $15 \mathrm{sec}$ at $95^{\circ} \mathrm{C}, 1$ minute at $59^{\circ} \mathrm{C}$; followed by a dissociation curve. Error was calculated as Standard Error of the Mean (SEM).

\section{Results and discussion}

Cloning and sequence analysis of the $\mathrm{ZnF}$ protein gene from $F$. arundinacea

Suppression subtractive hybridization (SSH) was used to identify differentially expressed genes related to salt stress in F. arundinacea. Analysis of the SSH library (SSH) revealed a partial clone coding for a $\mathrm{ZnF}$ protein. The preliminary screening of selected genes by RNA blot analysis confirmed that $\mathrm{FaZnF}$ was up-regulated by salt stress. BLAST search results indicated high homology to a transcription factor. Since transcription factors have the potential to regulate plant responses to multiple stresses and given the high homology of FaZnF to stress associated proteins across species, we focused our attention on this gene/protein as a possible transcription factor capable of directing the salt stress response in tall fescue.

The whole gene sequence was obtained using 3' RACE (See Figure 1; Genbank Accession JN790818, to be released in April). Sequence analysis showed a fulllength cDNA of 977 nucleotides, containing an open reading frame (ORF) of 501 nucleotides (ATG, 108-110; TAG, 609-611). To determine the function of this gene, this cDNA sequence was subjected to a BLAST search [50] against the nr nucleotide collection at the NCBI database and phylogenetic trees were constructed. The 
Table 1 Gene target information.

\begin{tabular}{|c|c|c|c|c|c|}
\hline Name & Top Reference Alignment & $\begin{array}{l}\text { Arabidopsis } \\
\text { Homolog }\end{array}$ & Position & $\begin{array}{l}\text { Forward primer } \\
\text { Reverse primer } \\
5^{\prime}-3^{\prime}\end{array}$ & $\begin{array}{c}\% \\
\text { efficiency }\end{array}$ \\
\hline elF1 & $\begin{array}{c}\text { ref|XP_478516.1| translational } \\
\text { initiation factor elF1 } \\
\text { Oryza sativa }\end{array}$ & AT1G20010 & 97 & $\begin{array}{l}\text { GAAGAACGTCTCAAATTTCCTCG } \\
\text { CAGTTGCTCAGAAACCATGAATC }\end{array}$ & 99 \\
\hline GST24 & $\begin{array}{c}\text { ref|XP_463733.1| } \\
\text { glutathione S-transferase GST } 24 \mid \\
\text { Oryza sativa }\end{array}$ & AT1G10370 & 80 & $\begin{array}{c}\text { AGAAGATCTCACCAACAAGAGC } \\
\text { TCGCCGTGGAGGAGAAC }\end{array}$ & 95 \\
\hline $\begin{array}{l}\text { Lipoxy- } \\
\text { genase L2 }\end{array}$ & $\begin{array}{c}\text { ref|XP_469655.1| lipoxygenase L-2; } \\
\text { Oryza sativa }\end{array}$ & AT1G72520 & 361 & $\begin{array}{l}\text { CACGAGCCTGCCATTGATTA } \\
\text { TGTGGTTGTTCTTGACGATGA }\end{array}$ & 98 \\
\hline MAPK1 & $\begin{array}{c}\text { ref|XP_470659.1| } \\
\text { Putative MAP } \\
\text { kinase } 1 \\
\text { Oryza sativa }\end{array}$ & AT3G45640 & 148 & $\begin{array}{l}\text { CCACGGAGAATTTGATAAAGGAAATAC } \\
\text { TCCATCAGATTATTCGCTCAAATCAAG }\end{array}$ & 95 \\
\hline $\mathrm{FaZnF}$ & $\begin{array}{c}\text { TIGR Transcript Assembly } \\
\text { TA567_4606 } \\
\text { Putative } \bar{Z} \text { n finger } \\
\text { Festuca arundinacea }\end{array}$ & $\mathrm{n} / \mathrm{a}$ & 632 & TGTGCTACCTCACCGTCA TCAGGATGCCCAACAACTAGA & 96 \\
\hline GAPDH & $\begin{array}{l}\text { TIGR Transcript Assembly } \\
\text { TA626_4606 } \\
\text { Glycerol aldehyde dehydrogenase } \\
\text { Festuca arundinacea }\end{array}$ & $\mathrm{n} / \mathrm{a}$ & 951 & $\begin{array}{l}\text { ATGGGTTATGTTGAGGAGGATT } \\
\text { TTGACGAAGTTGTCGTCAGAG }\end{array}$ & 99 \\
\hline$U B C$ & $\begin{array}{c}\text { TIGR Transcript Assembly DT703874 } \\
\text { Ubiquitin conjugating enzyme } \\
\text { Festuca arundinacea }\end{array}$ & $\mathrm{n} / \mathrm{a}$ & 239 & CGGCGGCTTCAACTACA CTCGCCAGCATAGAGTG & 102 \\
\hline
\end{tabular}

Quantitative PCR primers for each gene and the relative position of the amplicon (center) in the Tall Fescue genes/contigs are indicated. Amplicon length was designed to be between 75-125 bp. Gene target references are also noted along with the PCR efficiency of each primer set. Where applicable, the corresponding Arabidopsis gene reference number of genes found to be up-regulated in Arabidopsis plants overexpressing OsSAP11 [32] are included.

first gene listed on the BLAST results to $F a Z n F$ was from Triticum aestivum accession AK330210. The second gene on the list was a gene identified in osmotically stressed maize seedlings (Accession DQ244548) (See Phylogenetic Tree, Figure 2). Also included in the phylogenetic tree is "TA567_4606_Festuca" which was the top hit when $F a Z n F$ was subject to a BLAST search against the TIGR Plant Transcript Assemblies [51]. The identified ORF encoded a protein of 165 amino acids, with a potential molecular mass of $17.6 \mathrm{kDa}$ and a $\mathrm{pI}$ of 8.6 (Figure 1). Using a BLAST protein similarity search, an additional phylogenetic tree was constructed [40]. The protein was most closely related to a predicted protein from Hordeum vulgare subsp vulgare (Accession number BAK03538.1) and the OsSAP8 from rice (Os06g0612800) (See Figure 3). Finally, to identify the most closely related stress associated zinc fingers containing at least one of each of the A20/AN1 domains from rice (OsSAPs) and Arabidopsis (AtSAPs) as well as the most closely related Brachypodium A20/AN1 genes (Brachypodium distachyon Acc \#\#; Bradi\#\#), a phylogenetic tree was constructed. From this phylogenetic analysis, FaZnF was shown to be most closely related to Brachypodium Bradilg36050.1, OsSAP 8 and 4, and AtSAP2 (See Figure 4) [42]. A gene closely related to OsSAP8 that was isolated from indica rice (OsiSAP8) has been characterized extensively and was also induced in response to multiple abiotic stresses including salt, drought, temperature, desiccation, submergence, wounding, heavy metals and ABA [52]. An OsiSAP8/GFP fusion protein was shown to be localized to the cytoplasm and the A20 and AN1 zinc finger domains were shown to interact using the yeast two-hybrid system suggesting that this zinc finger protein may function via protein-protein interactions [52].

\section{Response of $\mathrm{FaZnF}$ to salt stress}

Since the $F a Z n F$ gene was initially isolated from salt stressed $F$. arundinacea plants, we wanted to investigate the kinetics of salt induced expression of this gene compared to the well characterized dehydration stress tolerance gene encoding a key enzyme in proline biosynthesis, delta 1-pyrroline-5-carboxylate synthetase (P5CS) [53]. Proline is an important osmoprotectant produced in plants in response to water related stresses [54-57] and recently was shown to be increased in tall fescue cultivars under drought stress conditions [58]. The P5CS gene has been shown previously to be involved in the biosynthesis of compatible solutes in response to salt stress in other plant species. Northern analysis of these two transcripts ( $F a Z n F$ and P5CS) was performed in plants exposed to $500 \mathrm{mM} \mathrm{NaCl}$ over a $24 \mathrm{hr}$ period. As shown in Figure $5 \mathrm{~A}, \mathrm{FaZnF}$ displayed a low level constitutive expression prior to salt stress $(0 \mathrm{hr})$ and remained relatively constant until it started increasing at $4 \mathrm{hr}$ post-stress induction and 


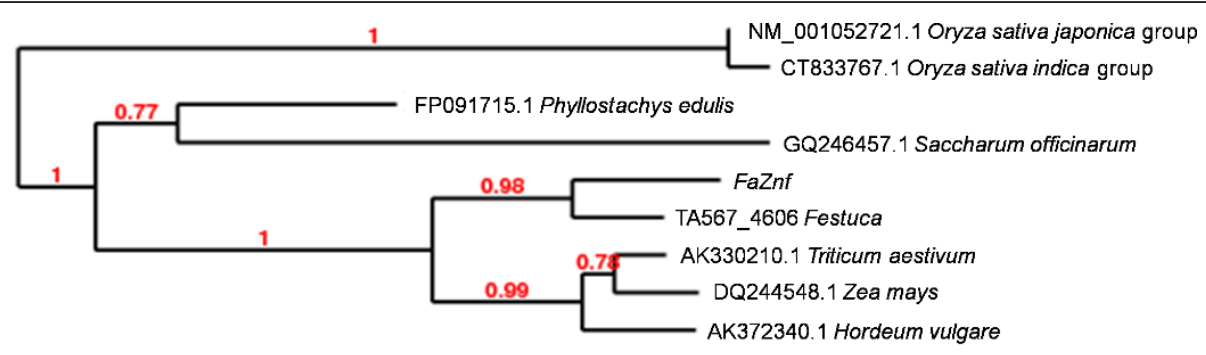

0.09

Figure 2 Phylogenetic tree of FaZnF and related genes. The top BLAST hits from each genera obtained when FaZnF was used for BLAST analysis at NCBI [49]. Also included is "TA567_4606_Festuca" which was the top BLAST hit when TIGR Plant Transcript Assembly http://plantta. jcvi.org/search.shtml was queried with FaZnF [50]. This transcript assembly contained ESTs from a heat stressed cDNA subtraction library from tall fescue [80] and was most closely related to FaZnF. The scale bar represents .09 nucleotide substitutions per site, or 9 nucleotide differences per 100 nucleotides. 


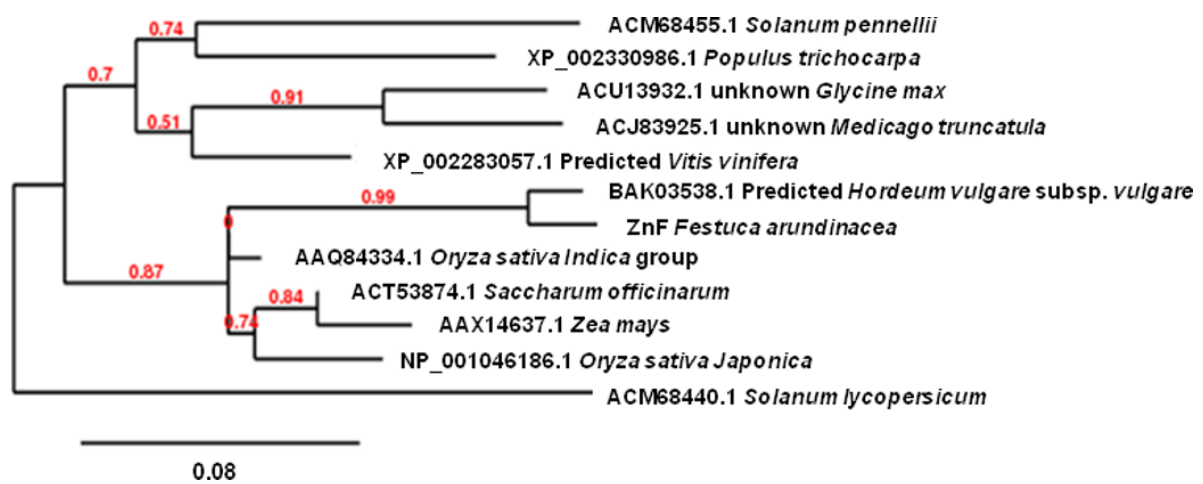

Figure 3 Phylogenetic tree of FaZnF and related proteins. The top BLAST hits from different genera (only the top hit from each genera is included) obtained when FaZnF was used for a protein BLAST analysis at NCBI [50]. The protein most closely related to FaZnF is a predicted protein from Hordeum vulgare which was identified in a subtraction CDNA library from seedling shoot and root treated with ABA. The scale bar represents .08 amino acid substitutions per site, or 8 amino acid differences per 100 amino acids.

continued to increase through $16 \mathrm{hr}$ and then decreased slightly from the 16-hr level to the 24-hr level. P5CS was not detectable prior to salt induction and started to increase slightly at $2 \mathrm{hr}$ post-induction, gradually increasing to a maximum at $16 \mathrm{hr}$ post-induction and slightly decreasing from that level at $24 \mathrm{hr}$.

To investigate the sensitivity of $\mathrm{FaZnF}$ and P5CS to different levels of salt stress, eight-week-old mature plants were treated with increasing concentrations of $\mathrm{NaCl}$ for 12 and $24 \mathrm{hr}$, and gene expression was assessed by Northern blot analysis. As shown in Figure 5B, FaZnF was expressed at a low level in the absence of salt (0), increased slightly at 12 and $24 \mathrm{hr}$ with both 100 and $200 \mathrm{mM}$ salt, but was increased greatly at 300, 400 and $500 \mathrm{mM} \mathrm{NaCl}$, indicating that FaZnF has a role in the salt stress response in tall fescue. P5CS started to show induction at 12 and $24 \mathrm{hr}$ with $200 \mathrm{mM}$ salt and increased steadily as the salt concentration increased to $500 \mathrm{mM}$.

The effect of different abiotic stresses on gene expression The expression patterns of P5CS and FaZnF genes were examined in response to various abiotic stress conditions. In Figure 6, as shown in the previous figures, both genes were activated by treatment with $500 \mathrm{mM} \mathrm{NaCl}$ for 12 and $24 \mathrm{hr}$. PEG treatments resulted in a slight elevation of the $F a Z n F$ gene at $12 \mathrm{hr}$, which was back to control levels at $24 \mathrm{hr}$. FaZnF gene was induced by heat (moderate increase at $8 \mathrm{hr}$ ), wilting (slight increase at $24 \mathrm{hr}$, greatly increased at $48 \mathrm{hr}$ ) and wounding similar to Osi$S A P 8$, but was not induced by cold or UV whereas OsiSAP8 was cold induced [52]. OsSAP4 was also shown to be induced by salt and dehydration [29]. Similar to most $S A P$ genes that have been studied in plants, $F a Z n F$ was induced by multiple abiotic stresses. P5CS showed a slight induction $8 \mathrm{hr}$ post UV treatment, during wilting (greatly increased at $48 \mathrm{hr}$ ), and was slightly increased after cold stress.

\section{Identification of possible targets of FaZnF}

By identifying conserved domains within FaZnF, potential targets can be predicted using published target lists of orthologous proteins. To identify possible targets of FaZnf, SMART analysis was utilized to predict conserved protein domains http://smart.embl-heidelberg.de/ . From this analysis, two specific zinc finger domains were identified including motif A20 (SMART accession SM00259) and zinc finger motif AN1 (SMART accession SM00154) with e-values of $1.53 \mathrm{e}-09$ and $5.15 \mathrm{e}-16$, respectively (Figure 1 ).

Some SAP proteins in Arabidopsis and rice have been localized to the nucleus [32,35] suggesting possible roles as transcription factors. Given the considerable amount of literature on A20/AN1 stress associated proteins (SAPs) in the model organism Arabidopsis, including microarrays documenting transcriptional changes in transgenic Arabidopsis overexpressing rice OsSAP11 or a protein that interacts with OsSAP11 (OsRLCK253) [32], we were able to compare a known Arabidposis A20/AN1 target list to the list of genes identified in the tall fescue salt SSH library. Of the 447 contig sequences from our salt SSH library, 38 sequences closely matched the Arabidopsis A20/AN1 data set through top reference alignment similarities. Confirmation of homology was then performed by tBLASTx analysis to Arabidopsis (SDSC workbench). Four representative contig sequences, each representative of a specific arm of the salt stress response, were identified and analyzed to determine if overexpression of $\mathrm{FaZnF}$ influences transcriptional activation; MAPK, GST24, lipoxygenase L-2 and $e I F 1$. 


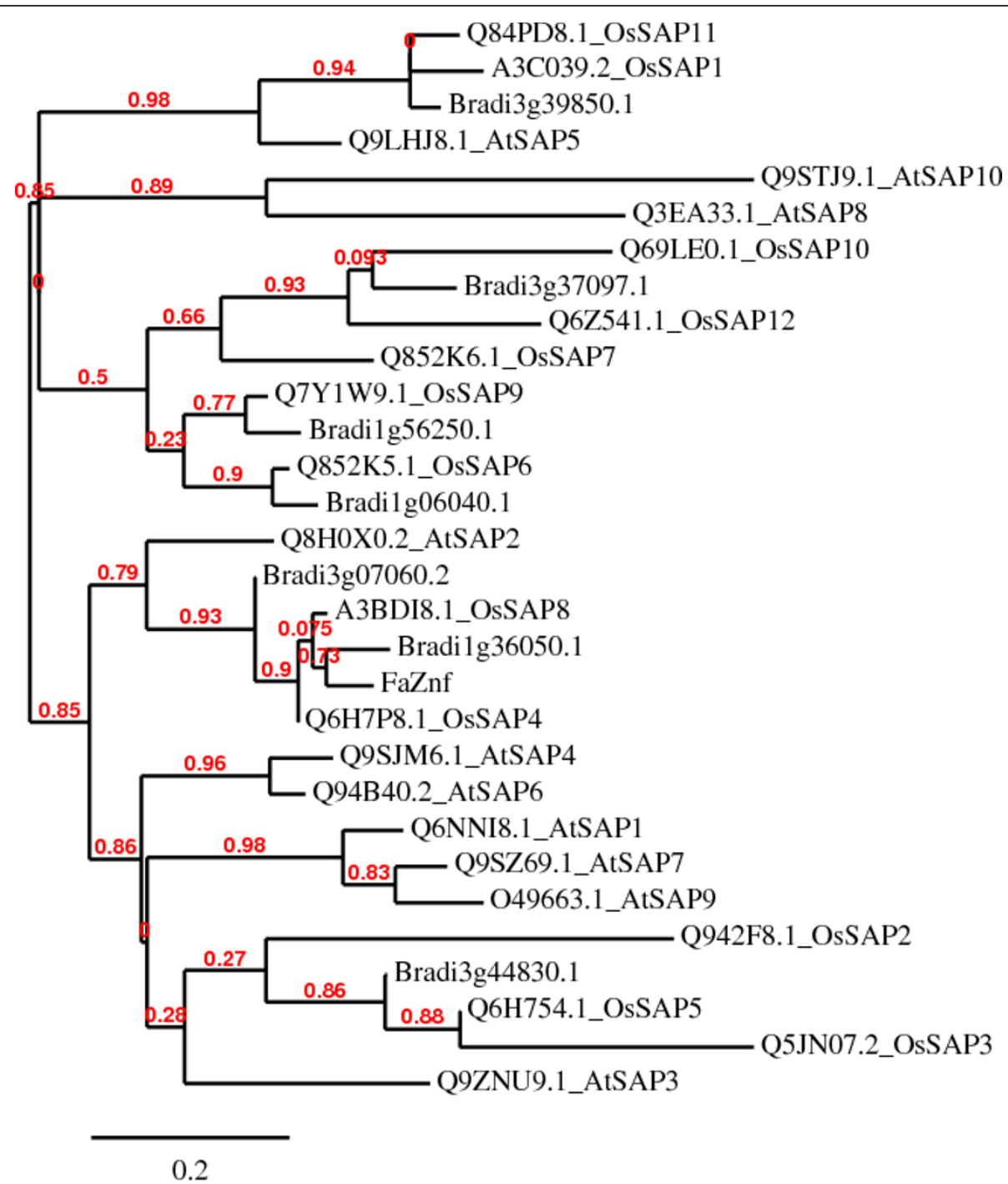

Figure 4 Alignment of Stress Associated Proteins. Alignment of Stress Associated Proteins (SAP) with both AN1/A20 domains from rice and Arabidopsis and most closely AN1/A20 domain-containing proteins from Brachypodium. FaZnF is most closely related to Brachypodium

Bradi1g36050.1 and OsSAP8. The scale bar represent 0.2 amino acid substitutions per site, indicating 2 amino acid differences per 10 amino acids.

MAPK gene expression is elevated in calli overexpressing FaZnF

Signal transduction through MAPK activation during salt stress is essential for activation of the high osmolarity glycerol pathway (HOG) [59] which in turn enables survival during high osmotic stress [60]. Though MAPK is posttranscriptionally activated through a cascade of phosphorylation events, transcriptional induction also occurs during salt stress in Arabidopsis [61]. Consistent with these observations, our salt subtraction library also indicates that MAPK transcription is induced with salt stress in F. arundinacea. However, the general mechanism of transcriptional activation of the MAPK gene during salt stress is not clear. To address whether FaZnF can influence the transcription of $M A P K$, RNA was isolated from control calli and calli overexpressing FaZnF and changes in transcription were quantified by RT qPCR. Collectively, these overexpressing calli showed an increase in FaZnF expression by greater than 12-fold compared to housekeeping genes GAPDH or UBC (Figure 7). Interestingly, expression of $M A P K$ was also increased almost 3-fold in overexpressing FaZnF calli, thus suggesting the possibility that the A20/AN1 domain containing FaZnF enzyme might regulate expression of $M A P K$, directly or indirectly.

\section{FaZnF influences transcription of oxidative stress pathway genes}

Abiotic stressors such as salt stress increase the production of Reactive Oxygen Species (ROS), thus activating the oxidative stress pathway. Enzymes such as glutathione 


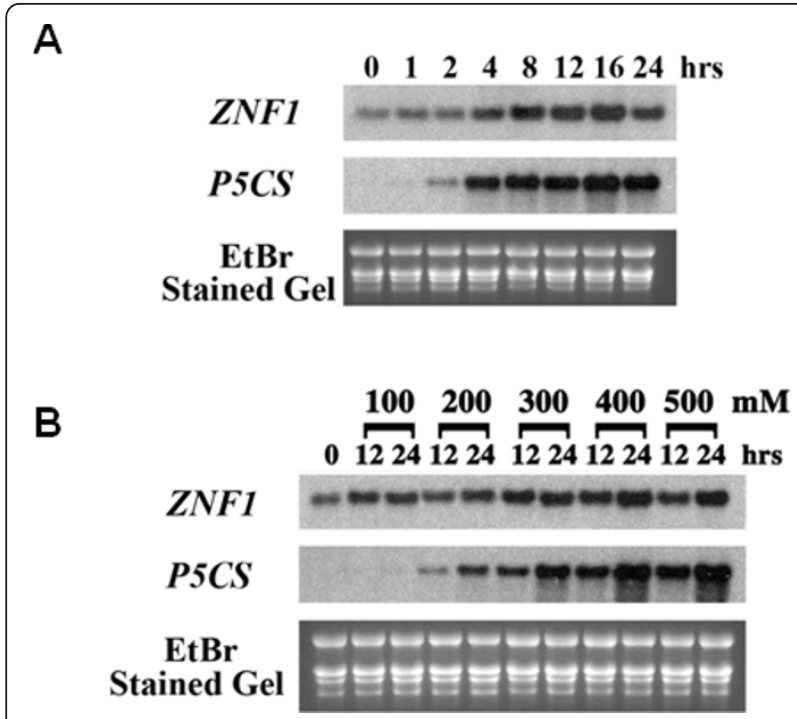

Figure 5 Northern Blot analysis of $F a Z n F$ and P5CS expression. (A) Northern Blot analysis of FaZnF and P5CS expression in response to salt stress for various time periods (0-24 hr). Total RNA was extracted from the aerial portions of plants that had been treated with $500 \mathrm{mM} \mathrm{NaCl}$ for the indicated number of hours. (B) Analysis of transcript levels of FaZnF and P5CS from plants treated with different levels of $\mathrm{NaCl}(0-500 \mathrm{mM})$ for 12 or $24 \mathrm{hr}$. Total RNA was extracted from the aerial portions of the plants that had been treated with different levels of $\mathrm{NaCl}$ (100-500 mM) for 12 or $24 \mathrm{hr}$, or with water $(0 \mathrm{hr}$ control). Ten $\mu \mathrm{g}$ of total RNA from each treatment was separated on a denaturing (formaldehyde) agarose gel. Equal loading was confirmed by visualization of the rRNA bands with ethidium bromide before (gel) and after transfer to the nylon membrane (blot). The RNA blots were hybridized with DIG-labeled DNA probes for ZNF1 and P5CS.

S-transferases are transcriptionally up-regulated to scavenge the elevated ROS to protect the organism [62]. Our salt subtraction library identified one major GST, GsT24 as being up-regulated with salt stress. Considering that overexpression of the highly homologous A20/AN1 SAP1 enzyme influenced transcription levels of many GSTs, experiments were performed to investigate whether FaZnF also influenced transcription of GsT24. Again, to determine transcriptional induction changes in mRNA, the expression of GsT24 was monitored in F. arundinacea control calli and FaZnF overexpressing calli by RT qPCR. Similar to MAPK expression, levels of GsT24 expression increased more than 5-fold in calli overexpressing FaZnF compared to control calli (Figure 7), strongly suggesting that this A20/AN1 protein influences the transcription of GsT24.

While combating oxidative stress, plants will utilize ROS as signaling molecules to either maximize the detoxification response or to accelerate cell death $[62,63]$. One way to intensify the production of ROS and potentially the oxidative stress response is through the up-regulation of lipoxygenases [64,65] which catalyze

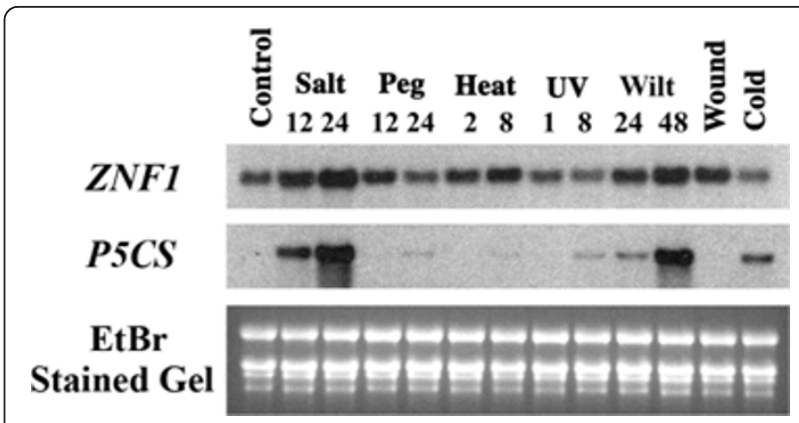

Figure 6 Gene expression analysis of $\mathrm{FaZnF}$ and P5CS after exposure to different abiotic stresses. Total RNA was extracted from the aerial portions of control plants (untreated and watered normally), from plants that had been subjected to different stresses for the indicated time periods, and from plants at specific time points after exposure to indicated stress (Salt: 500 mM NaCl; PEG: 12.87\% PEG 6000; Heat: $40^{\circ} \mathrm{C}$; UV: time after 5 min exposure to short-wave ultraviolet light; Wilting (Drought): no water for 24 or $48 \mathrm{hr}$; Wounding: $12 \mathrm{hr}$ after mechanically wounded 3-5 times perpendicularly across the leaves; Cold: $4^{\circ} \mathrm{C}$ for $24 \mathrm{hr}$. Ten $\mu \mathrm{g}$ of total RNA from each treatment was separated on a denaturing (formaldehyde) agarose gel. Equal loading was confirmed by visualization of the rRNA bands with ethidium bromide before (gel) and after transfer to the nylon membrane (blot). The RNA blots were hybridized with DIG-labeled DNA probes for ZNF1 and P5CS genes.

polyunsaturated fatty acid dioxygenation or pyridine nucleotide oxidation [66]. Many members of the lipoxygenase family are transcriptionally up-regulated with salt stress [67]. Similarly, lipoxygenase is up-regulated with salt stress in our salt SSH library, and overexpression of $\mathrm{FaZnF}$ results in a 3 -fold increase in lipoxygenase L-2 transcript levels compared to housekeeping genes as determined by RT qPCR (Figure 7).

To ensure the most efficient use of cellular resources during salt or oxidative stress, translation is restricted $[68,69]$. Translation efficiency can be reduced by posttranslational modification of the translation apparatus or through transcriptional regulation of key translation factors. However, similar to the heat shock stress response, the salt stress response can also be accompanied by salt stress recovery, where the cellular machinery anticipates increases in gene expression by increasing the transcription of translation factors [70]. Interestingly, overexpression of translation initiation factor eIF1A has been reported to increase salt tolerance in multiple organisms [71], and eIF1 was identified in our salt subtraction library as being up-regulated with salt stress. However, transcriptional analysis to determine whether overexpression of the A20/AN1 FaZnF results in increased eIF1 transcription did not show enhanced induction compared to housekeeping genes GAPDH or $U B C$ (Figure 7). This result suggests that additional signals during salt stress might be required for activation of this translation initiation gene. 


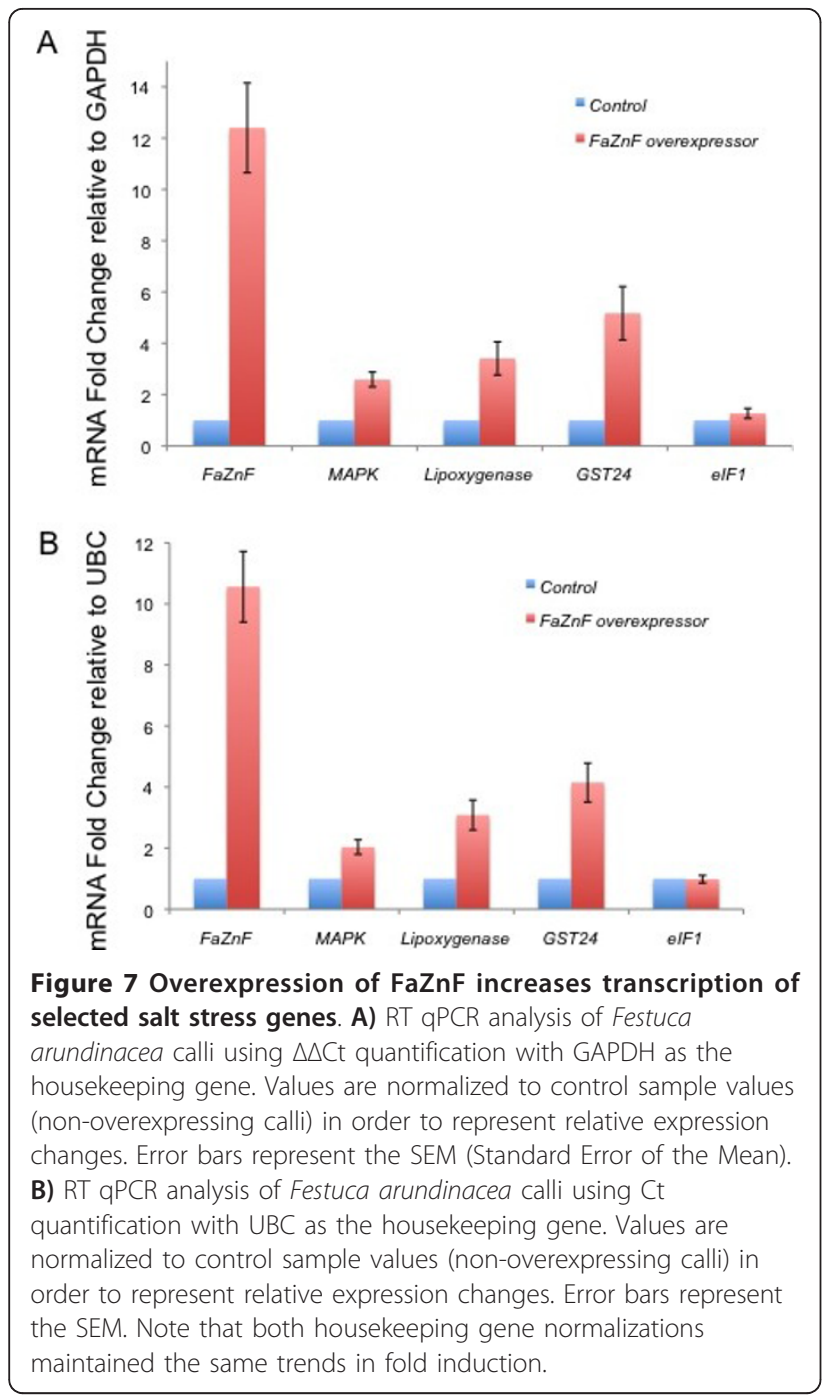

\section{Conclusions}

In summary, one of the biggest challenges to agricultural yield worldwide is increased soil salinity $[3,72]$. Plants responding to increased salinity have at least two survival response strategies: activation of the MAPK pathway to deal with subsequent osmotic stress, and activation of the oxidative stress pathway to deal with large increases in reactive oxygen species (ROS). For many plants, including forage crops such as $F$. arundinacea, increased soil salinity induces osmotic and oxidative stress responses [73]. However, the cellular mechanisms driving these stress responses in grasses have not been fully delineated. Here we describe a highly conserved, from humans to plants, Stress Associated Protein (SAP) that contains the unique combination of dual zinc finger motifs, A20/AN1, in the forage grass $F$. arundinacea. This protein could act both as a transcription factor in the nucleus and as a mediator of stability and function in the mitochondria and cytoplasm, similar to the mammalian stress factors p53 and XBP1 [74-77]. This work provides evidence that FaZnF is involved in the regulation of at least two pathways initiated by the salt stress response. It is not yet known if the FaZnF protein acts through ubiquitinrelated mechanisms like AtSAP5 [30] and animal ZNF216 proteins [78], or perhaps through interactions with protein kinases like OsSAP11/1 [32] and ZNF216 [79], or through interactions with other SAP/nonSAP proteins or transcription factors, or as a transcription factor itself.

Future studies are necessary to determine the cellular localization and mechanism of function for FaZnF, though it is quite possible that FaZnF has many functions as an abiotic stress factor, as do many stress related proteins. It will also be of additional interest to determine if overexpression of FaZnF will lead to greater abiotic stress tolerance in grasses.

\section{Additional material}

Additional file 1: Sequence of all genes/contigs used in this study are listed. Protein sequence of the open reading frame of FaZnF is also included. Note that primers used for quantitative RT-PCR are highlighted in yellow. Contigs refer to the contig number of clones from the Tall Fescue salt SSH library that were sequenced.

\section{Abbreviations}

ABA: abscisic acid; BLAST: basic local alignment search tool; CIM: callus induction medium; 2,4-D: 2,4-Dichlorophenoxyacetic acid; DNase: deoxyribonuclease; EDTA: ethylenediaminetetraacetic acid: FAO: Food and Agriculture Organization; FaZnF: Festuca arundinacea zinc finger protein; GST: glutathione-S-transferase; MAPK: mitogen-activated protein kinase; $\mathrm{NaCl}$ : sodium chloride; $\mathrm{NaPO}_{4}$ : combination of $\mathrm{NaH}_{2} \mathrm{PO}_{4}$ and $\mathrm{Na}_{2} \mathrm{HPO}_{4}$; P5CS: 1 pyrroline-5-carboxylate synthetase; PCR: polymerase chain reaction; PEG: polyethylene glycol; RACE: random amplification of cDNA ends; ROS: reactive oxygen species; RT qPCR: reverse transcription quantitative PCR; SAP: stress associated protein; SDS: Sodium dodecyl sulfate; SSH: suppression subtraction hybridization; UV: ultraviolet.

\section{Acknowledgements}

Special thanks is extended to Dr. Ming-Bo Wang and Dr. Richard Brettell (CSIRO, Canberra Australia) for providing the pVec8 plasmid, to Thomas Lockwood (USDA-ARS, Corvallis OR) for his invaluable inputs and work on the tissue culture, transformation experiments and Northern Analysis, and to Vicky Hollenbeck for cloning the FaZnF gene and construction of the pVec $\mathrm{FaZnF}$ vector. Experimental methods performed in this research complied with current laws and regulations of the U.S.A. The use of trade, firm, or corporation names in this publication is for the information and convenience of the reader. Such use does not constitute an official endorsement or approval by the United States Department of Agriculture or the Agricultural Research Service of any product or service to the exclusion of others that may be suitable.

Relevance to ARS National Programs. NP205: Rangeland, Pasture and Forages: Component "Plant Resources". NP302: Plant Biological and Molecular Processes: Component "Biological Processes that Determine Plant Productivity and Quality".

\section{Author details}

'USDA-ARS National Forage Seed Production Research Center, 3450 S.W. Campus Way, Corvallis, OR 97331. ${ }^{2}$ Applied Technology Center, 1050 Forrer Blv., Kettering, $\mathrm{OH} 45429$. 


\section{Authors' contributions}

$J E D, J C B$, and RCM conceived of the study and participated in its design. RCM was responsible for northern analysis and callus transformation. KGC designed and performed the RT QPCR analysis. RCM, KGC and JEB helped to draft the manuscript. All authors read and approved the final manuscript.

\section{Competing interests}

The authors declare that they have no competing interests.

Received: 28 September 2011 Accepted: 24 January 2012

Published: 24 January 2012

\section{References}

1. Wang W, Vinocur B, Altman A: Plant responses to drought, salinity and extreme temperatures: towards genetic engineering for stress tolerance. Planta 2003, 218:1-14.

2. Munns R: Genes and salt tolerance: bringing them together. New Phytol 2005, 167:645-663.

3. Food and Agriculture Organization, Rome: World agriculture: towards 2015/2030. Summary report. 2002 [http://www.fao.org/docrep/004/ y3557e/y3557e00.htm].

4. Deyholos MK: Making the most of drought and salinity transcriptomics. Plant Cell Environ 2010, 33:648-654.

5. Hirayama T, Shinozaki K: Research on plant abiotic stress responses in the post-genome era: past, present and future. Plant J 2010, 61:1041-1052.

6. Chinnusamy V, Schumaker K, Zhu JK: Molecular genetic perspectives on cross-talk and specificity in abiotic stress signalling in plants. J Exp Bot 2004, 55:225-236.

7. Yamaguchi-Shinozaki K, Shinozaki K: Transcriptional regulatory networks in cellular responses and tolerance to dehydration and cold stresses. Annu Rev Plant Biol 2006, 57:781-803.

8. Bartels D, Sunkar R: Drought and salt tolerance in plants. Crit Rev Plant Sci 2005, 24:23-58.

9. Munns R, Tester M: Mechanisms of salinity tolerance. Annu Rev Plant Biol 2008, 59:651-681.

10. Pardo JM: Biotechnology of water and salinity stress tolerance. Curr Opin Biotechnol 2010, 21:185-196.

11. Nakashima K, Ito Y, Yamaguchi-Shinozaki K: Transcriptional regulatory networks in response to abiotic stresses in Arabidopsis and grasses. Plant Physiol 2009, 149:88-95.

12. Hussain SS, Kayani MA, Amjad M: Transcription factors as tools to engineer enhanced drought stress tolerance in plants. Biotechnol Prog 2011, 27:297-306.

13. Peleg Z, Apse MP, Blumwald E: Engineering salinity and water-stress tolerance in crop plants. Adv Bot Res 2011, 57:405-443.

14. Miller J, McLachlan AD, Klug A: Repetitive zinc-binding domains in the protein transcription factor IIIA from Xenopus oocytes. EMBO J 1985, 4:1609-1614.

15. Klug A: The discovery of zinc fingers and their applications in gene regulation and genome manipulation. Annu Rev Biochem 2010, 79:213-231.

16. Sugano S, Kaminaka H, Rybka Z, Catala R, Salinas J, Matsui K, OhmeTakagi M, Takatsuji H: Stress-responsive zinc finger gene ZPT2-3 plays a role in drought tolerance in petunia. Plant $J$ 2003, 36:830-841.

17. Englbrecht CC, Schoof H, Böhm S: Conservation, diversification and expansion of $\mathrm{C} 2 \mathrm{H} 2$ zinc finger proteins in the Arabidopsis thaliana genome. BMC Genomics 2004, 5:39.

18. Agarwal $P$, Arora R, Ray $S$, Singh A, Singh $V$, Takatsuji $H$, Kapoor S, Tyagi A: Genome-wide identification of $\mathrm{C}_{2} \mathrm{H}_{2}$ zinc-finger gene family in rice and their phylogeny and expression analysis. Plant Mol Biol 2007, 65:467-485.

19. Sakamoto H, Maruyama K, Sakuma Y, Meshi T, Iwabuchi M, Shinozaki K, Yamaguchi-Shinozaki K: Arabidopsis Cys2/His2-type zinc-finger proteins function as transcription repressors under drought, cold, and highsalinity stress conditions. Plant Physiol 2004, 136:2734-2746.

20. Huang J, Yang $X$, Wang M-M, Tang H-J, Ding L-Y, Shen Y, Zhang H-S: A novel rice $\mathrm{C} 2 \mathrm{H} 2$-type zinc finger protein lacking DLN-box/EAR-motif plays a role in salt tolerance. Biochim Biophys Acta Gene Struct Expression 2007, 1769:220-227.

21. Pan L, Yang Q, Chi X, Chen M, He Y, Yu S: AhZFP1, a cDNA encoding $\mathrm{C} 2 \mathrm{H} 2$-type zinc finger protein, induced by salt stress in peanut (Arachis hypogaea L.). Bioinformatics and Biomedical Engineering (iCBBE), 2010 4th International Conference on June 18-20 2010, 1-7.

22. An Y, Wang $Y$, Lou $L$, Zheng $T$, Qu G-Z: A novel zinc-finger-like gene from Tamarix hispida is involved in salt and osmotic tolerance. $J$ Plant Res 2011, 124:689-697.

23. Gourcilleau D, Lenne C, Armenise C, Moulia B, Julien JL, Bronner G, LeblancFournier N: Phylogenetic study of plant Q-type $\mathrm{C}_{2} \mathrm{H}_{2}$ zinc finger proteins and expression analysis of poplar genes in response to osmotic, cold and mechanical stresses. DNA Res 2011, 18:77-92.

24. Sun S-J, Guo S-Q, Yang X, Bao Y-M, Tang H-J, Sun H, Huang J, Zhang H-S: Functional analysis of a novel Cys2/His2-type zinc finger protein involved in salt tolerance in rice. J Exp Bot 2010, 61:2807-2818.

25. Xu S, Wang X, Chen J: Zinc finger protein 1 (ThZF1) from salt cress Thellungiella halophila is a Cys-2/His-2-type transcription factor involved in drought and salt stress. Plant Cell Rep 2007, 26:497-506.

26. Opipari AW, Boguski MS, Dixit VM: The A20 CDNA induced by tumor necrosis factor alpha encodes a novel type of zinc finger protein. J Biol Chem 1990, 265:14705-14708.

27. Linnen JM, Bailey CP, Weeks DL: Two related localized mRNAs from Xenopus laevis encode ubiquitin-like fusion proteins. Gene 1993, 128:181-188.

28. Mukhopadhyay A, Vij S, Tyagi AK: Overexpression of a zinc-finger protein gene from rice confers tolerance to cold, dehydration, and salt stress in transgenic tobacco. Proc Natl Acad Sci USA 2004, 101:6309-6314.

29. Vij S, Tyagi AK: Genome-wide analysis of the stress associated protein (SAP) gene family containing A20/AN1 zinc-finger(s) in rice and their phylogenetic relationship with Arabidopsis. Mol Genet Genomics 2006, 276:565-575.

30. Kang M, Fokar M, Abdelmageed H, Allen R: Arabidopsis SAP5 functions as a positive regulator of stress responses and exhibits E3 ubiquitin ligase activity. Plant Mol Biol 2011, 75:451-466.

31. Ben Saad R, Zouari N, Ben Ramdhan W, Azaza J, Meynard D, Guiderdoni E, Hassairi A: Improved drought and salt stress tolerance in transgenic tobacco overexpressing a novel A20/AN1 zinc-finger gene isolated from the halophyte grass Aeluropus littoralis. Plant Mol Biol 2010, 72:171-190

32. Giri J, Vij S, Dansana PK, Tyagi AK: Rice A20/AN1 zinc-finger containing stress-associated proteins (SAP1/11) and a receptor-like cytoplasmic kinase (OsRLCK253) interact via A20 zinc-finger and confer abiotic stress tolerance in transgenic Arabidopsis plants. New Phytol 2011, 191:721-732.

33. Huang J, Wang M-M, Jiang $Y$, Bao Y-M, Huang $X$, Sun $H, X u$ D-Q, Lan $H-X$, Zhang H-S: Expression analysis of rice A20/AN1-type zinc finger genes and characterization of ZFP177 that contributes to temperature stress tolerance. Gene 2008, 420:135-144.

34. Xuan $N$, Jin $Y$, Zhang $H$, Xie $Y$, Liu Y, Wang G: A putative maize zinc-finger protein gene, ZmAN13, participates in abiotic stress response. Plant Cell Tiss Org Cult 2011, 107:1-12.

35. Dixit AR, Dhankher OP: A novel stress-associated protein 'AtSAP10' from Arabidopsis thaliana confers tolerance to nickel, manganese, zinc, and high temperature stress. PLOS ONE 2011, 6:e20921.

36. Engels JG, Rink R, Jensen K: Stress tolerance and biotic interactions determine plant zonation patterns in estuarine marshes during seedling emergence and early establishment. J Ecol 2011, 99:277-287.

37. Baldwin JC, Dombrowski JE: Evaluation of Lolium temulentum as a model grass species for the study of salinity stress by PCR-based subtractive suppression hybridization analysis. Plant Sci 2006, 171:459-469.

38. Wang M-B, Matthews PR, Upadhyaya MN, Waterhouse PM: Improved vectors for Agrobacterium tumefaciens-mediated plant transformation. Acta Hortic 1998, 461:401-407.

39. Wang MB, Upadhyaya MN, Brettell RIS, Waterhouse PM: Intron mediated improvement of a selectable marker gene for plant transformation using Agrobacterium tumefaciens. J Genet Breeding 1997, 51:325-334.

40. Altschul SF, Gish W, Miller W, Myers EW, Lipman DJ: Basic local alignment search tool. J Biol 1990, 215:403-410.

41. Marchler-Bauer A, Anderson JB, Chitsaz F, Derbyshire MK, DeWeese-Scott C, Fong JH, Geer LY, Geer RC, Gonzales NR, Gwadz M, et al: CDD: specific functional annotation with the Conserved Domain Database. Nucleic Acids Res 2009, 37:D205-D210.

42. Dereeper A, Guignon V, Blanc G, Audic S, Buffet S, Chevenet F, Dufayard JF, Guindon S, Lefort $V$, Lescot $M$, et al: Phylogeny.fr: robust phylogenetic analysis for the non-specialist. Nucleic Acids Res 2008, 36:W465-469. 
43. Rozen S, Skaletsky HJ: Primer3 on the WWW for general users and for biologist programmers. In Bioinformatics Methods and Protocols: Methods in Molecular Biology. Edited by: Krawetz S, Misener S. Totowa, NJ: Humana Press; 2000:365-386.

44. Molecular Cloning, A Laboratory Manual. Edited by: Sambrook J, Russel DW. Cold Spring Harbor, New York: Cold Spring Harbor Press; 2001:

45. Dalton SJ: Plant regeneration from cell suspension protoplasts of Festuca arundinacea Schreb, Lolium perenne $\mathrm{L}$ and Lolium multiflorum Lam. Plant Cell Tiss Org Cult 1988, 12:137-140.

46. Hofgen R, Willmitzer L: Storage of competent cells for Agrobacterium transformation. Nucleic Acids Res 1988, 16:9877.

47. Agro Induction Protocol.doc. [http://plant-tc.cfans.umn.edu/listserv/2002/ log0206/msg00166.html].

48. Bustin SA, Benes V, Garson JA, Hellemans J, Huggett J, Kubista M, Mueller R, Nolan T, Pfaffl MW, Shipley GL, et al: The MIQE guidelines: Minimum information for publication of quantitative real-time PCR experiments. Clin Chem 2009, 55:611-622.

49. Livak KJ, Schmittgen TD: Analysis of relative gene expression data using real-time quantitative PCR and the 2(-Delta Delta $C(T))$ method. Methods 2001, 25:402-408.

50. Zhang Z, Schwartz S, Wagner L, Miller W: A greedy algorithm for aligning DNA sequences. J Comput Biol 2000, 7:203-214.

51. Childs KL, Hamilton JP, Zhu W, Ly E, Cheung F, Wu H, Rabinowicz PD, Town CD, Buell CR, Chan AP: The TIGR plant transcript assemblies database. Nucleic Acids Res 2007, 35:D846-851

52. Kanneganti V, Gupta AK: Overexpression of OsiSAP8, a member of stress associated protein (SAP) gene family of rice confers tolerance to salt, drought and cold stress in transgenic tobacco and rice. Plant Mol Biol 2008, 66:445-462.

53. Hu C-AA, Delauney AJ, Verma PS: A bifunctional enzyme ( $\Delta^{\prime}$-pyrroline-5carboxylate synthetase) catalyzes the first two steps in proline biosynthesis in plants. Proc Natl Acad Sci USA 1992, 89:9354-9358.

54. Delauney AJ, Verma DPS: Proline biosynthesis and osmoregulation in plants. Plant J 1993, 4:215-223.

55. Yoshiba Y, Kiyosue T, Nakashima K, Yamaguchi-Shinozaki K, Shinozaki K: Regulation of levels of proline as an osmolyte in plants under water stress. Plant Cell Physiol 1997, 38:1095-1102.

56. Kishor PBK, Sangam S, Amrutha RN, Laxmi PS, Naidu KR, Rao KRSS, Rao S, Reddy KJ, Theriappan P, Sreenivasulu N: Regulation of proline biosynthesis, degradation, uptake and transport in higher plants: Its implications in plant growth and abiotic stress tolerance. Curr Sci 2005, 88:424-438.

57. Szabados L, Savouré A: Proline: a multifunctional amino acid. Trends Plant Sci 2010, 15:89-97.

58. Man D, Bao Y-X, Han L-B: Drought tolerance associated with proline and hormone metabolism in two tall fescue cultivars. HortScience 2011, 46:1027-1032.

59. Covic L, Silva NF, Lew RR: Functional characterization of ARAKIN (ATMEKK1): a possible mediator in an osmotic stress response pathway in higher plants. Biochim Biophys Acta Gene Regul Mech 1999, 1451:242-254.

60. Westfall PJ, Patterson JC, Chen RE, Thorner J: Stress resistance and signal fidelity independent of nuclear MAPK function. Proc Natl Acad Sci USA 2008, 105:12212-12217.

61. Mizoguchi T, Irie K, Hirayama T, Hayashida N, Yamaguchi-Shinozaki K, Matsumoto K, Shinozaki K: A gene encoding a mitogen-activated protein kinase kinase kinase is induced simultaneously with genes for a mitogen-activated protein kinase and an $\mathrm{S} 6$ ribosomal protein kinase by touch, cold, and water stress in Arabidopsis thaliana. Proc Natl Acad Sci USA 1996, 93:765-769.

62. Pitzschke A, Forzani C, Hirt H: Forum Review: Reactive oxygen species signaling in plants. Antioxid Redox Signal 2006, 8:1757-1764.

63. Van Breusegem F, Dat JF: Reactive oxygen species in plant cell death. Plant Physiol 2006, 141:384-390.

64. Spiteller G: The relationship between changes in the cell wall, lipid peroxidation, proliferation, senescence and cell death. Physiol Plant 2003, 119:5-18.

65. Roy P, Roy SK, Mitra A, Kulkarni AP: Superoxide generation by lipoxygenase in the presence of NADH and NADPH. Biochim Biophys Acta Lipids Lipid Met 1994, 1214:171-179.
66. Needleman P, Truk J, Jakschik BA, Morrison AR, Lefkowith JB: Arachidonic Acid Metabolism. Annu Rev Biochem 1986, 55:69-102.

67. Kreps JA: Transcriptome changes for Arabidopsis in response to salt, osmotic, and cold stress. Plant Physiol 2002, 130:2129-2141.

68. Shenton D: Global translational responses to oxidative stress impact upon multiple levels of protein synthesis. J Biol Chem 2006, 281:29011-29021.

69. Rausell A, Kanhonou R, Yenush L, Serrano R, Ros R: The translation initiation factor elF1A is an important determinant in the tolerance to $\mathrm{NaCl}$ stress in yeast and plants. Plant J 2003, 34:257-267.

70. Gu R, Fonseca S, Puskas LG, Hackler LJ, Zvara A, Dudits D, Pais MS: Transcript identification and profiling during salt stress and recovery of Populus euphratica. Tree Physiol 2004, 24:265-276.

71. Diédhiou CJ, Popova OV, Dietz KJ, Golldack D: The SUI-homologous translation initiation factor elF-1 is involved in regulation of ion homeostasis in rice. Plant Biol 2008, 10:298-309.

72. Zhu J-K: Plant salt tolerance. Trends Plant Sci 2001, 6:66-71.

73. Hasegawa PM, Bressan RA, Zhu J-K, Bohnert HJ: Plant cellular and molecular responses to high salinity. Annu Rev Plant Physiol Plant Mol Biol 2000, 51:463-499.

74. Mihara M, Erster S, Zaika A, Petrenko O, Chittenden T, Pancoska P, Moll UM: p53 has a direct apoptogenic role at the mitochondria. Mol Cell 2003, 11:577-590.

75. Morselli E, Galluzzi L, Kroemer G: Mechanisms of p53-mediated mitochondrial membrane permeabilization. Cell Res 2008, 18:708-710.

76. Zhou Y, Lee J, Reno CM, Sun C, Park SW, Chung J, Fisher SJ, White MF, Biddinger SB, Ozcan U: Regulation of glucose homeostasis through a XBP-1-FoxO1 interaction. Nat Med 2011, 17:356-365.

77. Yoshida H, Uemura A, Mori K: pXBP1(U), a negative regulator of the unfolded protein response activator pXBP1(S), targets ATF6 but not ATF4 in proteasome-mediated degradation. Cell Struct Funct 2009, 34:1-10.

78. Hishiya A, Lemura S, Natsume T, Takayama S, Ikeda K, Watanabe K: A novel ubiquitin-binding protein ZNF216 functioning in muscle atrophy. EMBO J 2006, 25:554-564.

79. Huang J, Teng L, Li L, Liu T, Chen D, Xu LG, Zhai Z, Shu HB: ZnF216 is an A20-like and IKB kinase $\gamma$-interacting inhibitor of NFKB activation. J Biol Chem 2004, 279:16847-16853.

80. Zhang Y, Mian MA, Chekhovskiy K, So S, Kupfer D, Lai H, Roe BA: Differential gene expression in Festuca under heat stress conditions. J Exp Bot 2005, 56:897-907.

\section{doi:10.1186/1756-0500-5-66}

Cite this article as: Martin et al:: Identification and characterization of a salt stress-inducible zinc finger protein from Festuca arundinacea. BMC Research Notes 2012 5:66.

\section{Submit your next manuscript to BioMed Central and take full advantage of:}

- Convenient online submission

- Thorough peer review

- No space constraints or color figure charges

- Immediate publication on acceptance

- Inclusion in PubMed, CAS, Scopus and Google Scholar

- Research which is freely available for redistribution

Submit your manuscript at www.biomedcentral.com/submit
C Biomed Central 